\title{
Citizenship as a Constitutional Right and a Fundamental Condition for Exercising Diplomatic Protection
}

\author{
Arjana Llano \\ Doctor of Science Candidate, lecturer at University Ismail Qemali Vlore Albania, \\ Department of Justice, Vlore, Albania, \\ Email ariana-llano@live.com
}

\section{Doi:10.5901/mjss.2014.v5n2p417}

\section{Abstract}

This work is aimed at specifying how citizenship is obtained and what people with dual citizenship and people with no citizenship should do in their case. Citizenship is a fundamental right of individuals for the reason that in some cases it is the basis for enjoying other rights related to citizenship. Whether a given state of citizenship should claim or not diplomatic protection in case of dual citizenship against another state of citizenship is not just a case of academic interest. It may cause practical problems in a world where people leave their country in search of more freedom and rights. As a general rule, in case of dual citizenship, both countries of citizenship are entitled to have claims against a third country in the name of the concerned citizen. In international law, the diplomatic protection offered to individuals that reside in a given territory under the protection of a country that exercises no sovereignty over such territory is a familiar issue. Individuals living in protectorates, mandates or territories under custody have occasionally received diplomatic protection by the managing authorities; however, this practice is somehow limited by the institutional relation between the managed country and the managing one, and in every case it depends on the country against which such a protection is to be exercised. I have employed theoretical and empirical research methods for examining real cases.

Keywords: citizenship, diplomatic protection, individual, birth

\section{Introduction}

Citizenship is the juridical relationship existing between the individual and the state ${ }^{1}$. It is not only a legal concept, but also a multidimensional component with political, psychological and sociological implications. At the political level, citizenship is the status of a natural person, who is related to the state by loyalty ties. Form the sociological point of view citizenship is the feeling of belonging to a particular group. Whereas, from the psychological perspective, citizenship is a mental state that relates individuals to political facts. The correct application of the diplomatic protection principle relies on the pretended citizenship. For the pretension to be acceptable, by customary international law the pretending state should place a legal interest on assuming the case. Such a legal interest is claimed when an injured individual is the citizen of the pretending country. Therefore diplomatic protection is to be exercised only by that state, whose citizen is the injured individual. The relation between the state exercising the diplomatic protection and the individual asking for that protection is a sine qua non condition of the diplomatic protection rulings.

\section{Acquisition of Citizenship}

Citizenship is a fundamental right of individuals for the reason that in some cases it is the basis for enjoying other rights related to citizenship. The vital importance of citizenship is described by the USA Supreme Court Chairman as "the right to enjoy rights" ${ }^{2 \prime}$. The right to citizenship is reflected in article 15 of UDHR. Subsequent conventions of human rights such as CCPR and ECHR encourage the importance of citizenship. The European Convention on citizenship provides the right to multiple citizenships. Based on these international instruments almost all contemporary constitutions provide the right of the individual to citizenship, although the conditions for acquiring that citizenship differ from one legislation to another. The second part of the Albanian Constitution, containing the general principles of fundamental human rights and

\footnotetext{
${ }^{1}$ Arben Puto, International Public Law, Albin, 2008, p.268.

2 Natalie Klein, Lise Barry, A human rights perspective on diplomatic protection: David Hicks and his dual nationality, Australian Journal of Human Rights, V.13, 2007, p.4
} 
freedoms, provides the right to citizenship. According to article 19 of this constitution "Everyone who is born of at least one parent with Albanian citizenship gains automatically Albanian citizenship", and such right is in no case ever denied. The statement shows that our country is aligned with those countries where the well-known international principle jus sanguinis is applied. The constitution provides also that the citizenship is acquired in other circumstances pursuant to law. The determination of the Albanian citizenship is a basic element for obliging a state to protect the citizens of that state and let them enjoy certain constitutional rights related to the juridical fact of citizenship, i.e. the active and passive right to vote. The international law doesn't deal extensively with citizenship. The 1923's Nationality Decrees in Tunis and Marocco, state as follows: "Thus, in the present state of international law, questions of nationality are, in principle within this reserved domain."

This position has been confirmed by article 1 of the Convention of Hague on some issues related to nationality conflicts - 1930, according to which "It is for each State to determine under its own law who are its nationals". However, international law, in determining the rules of citizenship, sets some external limits to the relevant states. This was supported by International Court of Human Rights in its advisory opinion on "Proposed Amendments to the Naturalization Provisions of the Constitution of Costa Rica", according to which, it is necessary that the principles of nationality within a state's jurisdiction comply with the principle that international law sets some limits related to the conditions established by the international system for the protection of human rights 4 . Birth (jus soli) and origin (jus sanguinis) are recognized by international law as factors related to a state's citizenship. Naturalization is also known as a satisfactory condition for granting citizenship for the purpose of diplomatic protection. International law does not acknowledge naturalization in all circumstances. Naturalization acquired by deception and naturalization granted in a way that discriminates on racial or sex basis are examples of unacceptable naturalization. Naturalization cannot be recognized for the purposes of diplomatic protection if it is granted under the circumstance of no connection with the state. In this case, the denial is based on the abuse of the state which grants the citizenship through a mala fide process.

The International Court of Human Rights was based on this argument for the Nottebohm case. The court considered the way in which citizenship had been granted to Nottebohm by Lichtenstein and concluded that, by granting the citizenship in such a hurry, this state had failed to follow the deadline provisions. An important argument raised in the jurisprudence of international courts concerning the citizenship of natural persons has been the shift from a formal citizenship to an effective one, which appears also in Nottebohm case. Emphasis was placed on the real relation between the individual and the state assuming his pretention. However, this shift does not necessarily indicate a liberal interpretation of the principle of citizenship ${ }^{5}$. In a world where millions of people have left their country of citizenship and have been living in other countries, whose citizenship they have never obtained, the rigorous application of the effective citizenship concept would exclude these millions of people from the benefits of diplomatic protection, thus creating a category of undefended persons ${ }^{6}$. In this case there are different academic opinions. Some authors disapprove the rule of real connection as a rule of customary international law. They support the idea that often there are no strong ties between the individual, whom citizenship has been granted by jus soli or jus sanguinis, and that it is hard to limit the real connections in cases of naturalization. Some other authors tend to accept the real connection. Brownlie argues that such rule was based on literature prior to the Nottebohm case, and that it matters as a general principle with several application possibilities even outside the context of dual citizenship ${ }^{7}$. A general rule of customary international law is that of continuous citizenship. This rule - first proposed by Garcia Amador - provides that the individual should be protected under that condition that he holds the citizenship of the pretending state from the moment of the injury to the resolution of such pretension. The rule is aimed at preventing the injured person from obtaining another citizenship for benefit. However, such rule has been subject to some critics, for the reason that apart from the difficulty of correctly defining these two important moments, it may cause some inconveniency in those cases where the change of citizenship is accidental or involuntary. In such cases, the rigorous application of the rule would make the pretension unacceptable ${ }^{8}$. Accordingly this principle may case difficulties in those cases where an individual may change his citizenship, for reasons not related to diplomatic protection. However, the suggestions for abandoning this rule have failed to materialize due to the argument that this might lead to abuses and establishment of a "citizenship market" for purposes of diplomatic protection. Article 5 of the Convention of Human Rights project accepts the rule of continuous citizenship, although with

\footnotetext{
${ }^{3}$ Nationality Decrees issued in Tunis and Morocco on Nov. $8^{\text {th }}$, 1921, Advisory Opinion, $1923 \mathrm{P} / \mathrm{c} / \mathrm{l} / \mathrm{J}$

4 John Dugard, First report on diplomatic protection, UN doc. A/CN.4/506 p.100 pp.36

${ }^{5}$ Diplomatic protection v. Delocalization, The Jean Monnet Center for International and Regional

${ }^{6}$ Dugard, section 41

7 Ian Brownlie, Principles of Public International Law 1998, Oxford, Fifth Edition, p.412

${ }^{8}$ Draft articles with commentary, p36.
} 
some exclusions. The first section states the classical principle that a state is entitled to exercise diplomatic protection in respect of an individual who has been a citizen of that state at the time of the injury and on the day of the official submission of the pretension. However, it is not clear if a citizen should have continuous citizenship between these two dates, for the reason that, practically, such issues are rarely considered. The Convention of Human Rights states that it has exercised a progressive development of law when it established the rule that an injured person should continuously be a citizen from the moment of the injury to the submission of the pretension. Considering the difficulties of providing continuity evidences, it is presumed that the same citizenship exist on both dates. However, this presumption is assailable $^{9}$. The first requirement for fulfilling the rule of continuity is that the injury occurs on the day the injured individual has been a citizen of the state that submitted the pretension. It is necessary that the day of injury is a fix date, but it may extend to a period of time if the injury occurs in some acts or a continuous act along a period of time. The second requirement relates to the date of official submission of the pretension. The term submission of the pretension is used in treaties, judgments and doctrine to indicate the most distant date or dies ad quem (the day when) diplomatic protection is exercised.

\section{Diplomatic Protection to Persons with Dual Citizenship}

Dual citizenship is a fact in the life of international community. An individual may obtain multiple citizenships as a result of the parallel application of jus soli and jus sanguinis principles or by naturalization and irremovability of previous citizenship. Such a phenomenon has caused some problems with the application of diplomatic protection should a state want to protect a citizen against another state of citizenship. Although several countries deny dual citizenship by law, the international law provides no such a denial. Dual citizenship generates practical difficulties for governments to protect their citizens. The US government recognized the existence of dual citizenship, although it does not encourages it due to the eventual complications that may arise. The possible claims of other states on American citizens with dual citizenship may not comply with the USA laws and they may limit the attempts of the American government to assist US citizens abroad. Such arguments have been promoted even by other governments ${ }^{10}$. The rules established in the Convention of Hague 1930 and the customary international law proves the existence of both principles related to diplomatic protection in cases of dual citizenship. The first principle, which refers to the purpose of diplomatic protection, is a principle of international public law based on the sovereign equity of states in matters of citizenship, which prohibits diplomatic protection to those citizens who, at the same time, are citizens of a sued state. The second principle originates from international private law. It is based on the principle of effectiveness in the sense of dominant citizenship and it is related to the individual, not to the state. Court judgments and legal texts rapidly moved this principle within the ambit of international public law ${ }^{11}$. Article 4 of the Convention of Hague should be handled with the maximum care, not only for the reason that 80 years have passed since its adoption, but also because, since then, many modifications have been made to the concept of diplomatic protection. This concept is still undergoing a transformation process. In the end of the fifties the attitude to dual citizenship changed and adapted to the new globalist realities. The adoption of these changes resulted in the modification of the legislation related to citizenship at European level. In 1993, the European Council adopted a protocol and in 1997 it adopted a new European Convention on citizenship. By recognizing the liberty of each state to decide on the acknowledgment of dual citizenship, the Convention focuses on finding appropriate solutions in cases of dual citizenships. Article 17/2 states that its provisions on dual citizenship do not affect the provisions of international law related to diplomatic protection offered by a given state in respect of a citizen, who, at the same time, is a citizen of another state. Empirical data concerning the exercise of diplomatic protection in respect of citizens with dual citizenship are not common. However, these data encourage the principle of dominant or effective citizenship. Great Britain applies this principle by adopting the rules of year 1985, which state that "The government of Her Majesty shall not initiate claims against a state in case a British citizen is, at the same time, a citizen of that state ${ }^{12 "}$. The principle of dominant citizenship was adopted by Garcia Amador with article 21/4, emphasizing that "in cases of dual citizenship or multiple citizenships, the right to submit claims will pertain only to the state that has more real and stronger legal ties with the citizen subject to the claim ${ }^{13}$ ". One essential disagreement with the principle of dominant or effective citizenship is the

\footnotetext{
${ }^{9}$ Idem.

${ }^{10}$ Australian Department of Foreign Affairs and Trade, Canadian Department of Foreign Affairs Dual citizenship: what travelers should know: UK Home Office, Immigration and Nationality Directorate.

${ }^{11}$ D.J.Harris, Cases and materials on international law, Fifth Edition, Sweet \& Maxwell, 1998, p.600

12 D.J.Harris, Cases and materials on international law, Sweet \& Maxwell, 1998, p.601

${ }^{13}$ Garcia Amador, State responsibility, Third report, yearbook 1958, UN docA/CN.4/111 p.61
} 
unacceptability of its conditions. Some authors argue that residence is an evidence of effective connection, while others emphasize the voluntary act of naturalization. The judiciary practice, in establishing the dominant citizenship, considers certain factors as the usual residence, the time passed in each country, the date of naturalization, employment and financial interests, family relations, birth and marriage registrations with the embassy of the other state of citizenship, involvement in public and social life etc. However, none of these factors plays the decisive role and the value of each factor depends on the circumstances of the particular case. ${ }^{14}$ Whether a given state of citizenship should claim or not diplomatic protection in case of dual citizenship against another state of citizenship is not just a case of academic interest. It may cause practical problems in a world where people leave their country in search of more freedom and rights. This is the case of the well-known journalist Zahra Kazemi, a Canadian-Iranian citizen, who was arrested on June 2003 by the Iranian authorities as she was shooting photos of a local prison. She suffered physical tortures and after some days in coma, she died on July. In response to the protests of the Canadian state, Iran claimed that Kazemi was born in Iran and still was a citizen of Iran. Therefore Canada should not intervene in her case. The Canadian diplomatic representatives had not been allowed to attend the trial against an Iranian security officer. In response to this attitude, Canada called its ambassador in Iran and threatened to take further measures to the submission of a law suit with the International Court of Justice. The Kazemi case generated two arguments concerning the nature of diplomatic protection that might obstacle Canada from claiming justice with the International Court of Justice for the murder of a Canadian citizen. The first argument refers to the exhaustion of local instruments and the way it applies in Iran. Accordingly, Canada should wait for the trial performed by the Iranian authorities and then submit its claim. The second argument refers to the dual citizenship of Kazemi. Should the principle of effective citizenship be applied as described in the main project, the chances are that Canada submits a law suit with the International Court of Justice. In conclusion, we may say that in the case of dual citizenship there are two issues to be addressed. First, which of the states of citizenship should submit a claim in respect of the individual, and second which of the states of citizenship would be able to exercise diplomatic protection against the other state of citizenship? As far as the first issue is concerned, as a general rule, in case of dual citizenship, both countries of citizenship are entitled to have claims against a third country in the name of the concerned citizen. As we stated above, international law is moving beyond the theory of effective citizenship presented in Nottebohm case. Whether or not a state of citizenship should exercise diplomatic protection against another state of citizenship is regulated by article 7 . From the commentary of article 7 we recall that it has always been supported the idea that a state of citizenship cannot exercise diplomatic protection against another state, whose citizen is the individual subject to diplomatic protection. However, there have been some positive arguments for allowing a state of citizenship to exercise diplomatic protection against another state of citizenship should the claiming state be the state of dominant or effective citizenship. This means that a state of citizenship with which the individual has a dominant relation should be allowed to submit a claim against another state of citizenship should the individual suffer injury.

\section{Protection to Stateless Persons}

The general rule followed by the institution of diplomatic protection is that a state may exercise diplomatic protection only in respect of its citizens. Diplomatic protection has been traditionally related to the nationality of the state that exercises such diplomatic protection. In international law, the diplomatic protection offered to individuals that reside in a given territory under the protection of a country that exercises no sovereignty over such territory is a familiar issue. Individuals living in protectorates, mandates or territories under custody have occasionally received diplomatic protection by the managing authorities; however, this practice is somehow limited by the institutional relation between the managed country and the managing one, and in every case it depends on the country against which such a protection is to be exercised. ${ }^{15}$ The traditional theory fails to consider the status of stateless persons or refugees. This attitude does not comply with the contemporary international law concerning this category of people. ${ }^{16}$ Refugees represent a special category of people, as they are not eligible to receive protection from the state of citizenship. If a refugee requires the protection of his state of citizenship, then he will lose his refugee status. Protection to stateless persons and refugees is provided within the conventions on human rights. However this is a very limited protection for the reason that most states have failed to adopt such instruments or the right of the individual to submit claims before the monitoring authorities. Conventions referring to stateless persons or refugees have failed to deal

\footnotetext{
14 John Dugard, First Report on diplomatic protection, s.153, p.52

15 John Dugard, First Report on diplomatic protection, UN doc/A/CN.4/538, p.2

${ }^{16}$ Convention on the Reduction of Statelessness of year 1961 and Convention relating to the Status of Refugees of year 1951
} 
satisfactorily with diplomatic protection. ${ }^{17}$ The Convention relating to the Status of Refugees of year 1951 states that the issue of certain documents does not imply that the holder of such documents is entitled to diplomatic protection from the authorities of the country of issue, and such authorities are not entitled to exercise diplomatic protection. On the other hand, the Convention on the Reduction of Statelessness of year 1961 fails to consider the individual subject to diplomatic protection. In view of the given circumstances, it has been suggested that the state where the refugee or the stateless person has resided for a considerable period of time and to which this individual is effectively related, should be entitled to exercise diplomatic protection. The European Convention on Consular Functions of year $1967^{18}$ establishes a protection system to stateless persons. Article 46.1 of this convention provides that: "A consular officer of the State where a stateless person has his habitual residence, may protect such a person, provided that the person concerned is not a former national of the receiving State". Article no.8 of the Convention on Human Rights deals with the diplomatic protection of stateless persons. This article provides no definition of stateless persons. Such definition is however to be founded in the Convention relating to the status of stateless persons of year 1954, which defines a stateless person as someone who is "not considered as a national by any state under the operation of its law". A state may exercise diplomatic protection in respect of such a person, regardless of how he or she became stateless, provided that her or she was lawfully and habitually resident in that State both at the time of inquiry and at the date of the official presentation of the claim. Habitual residence in this context is intended to convey continuous residence ${ }^{19}$ Paragraph 2 deals with the diplomatic protection of refugees by their state of residence. Lawful residence and habitual residence are required as precondition for the exercise of diplomatic protection of refugees. The term "refugee" in Paragraph 2 is not limited to refugees as defined in the 1951 Convention relating to the Status of Refugees, but is intended to cover persons who do not strictly confirm to this definition. However, the Commission preferred to set no limit to the term in order to allow a State to extend diplomatic protection to any person that it recognized and treated like a refugee ${ }^{20}$ Such recognition must, however, be based on "internationally accepted standards". The temporal requirements for the bringing of the claim are repeated in this case. The refugee must be a lawful and habitual resident both at the time of the injury and at the date of the official presentation of the claim. Paragraph 3 provides that a State may not exercise diplomatic protection in respect of a refugee against the state of nationality of the refugee. To have permitted this would have contradicted the basic principle of citizenship as a predominant basis for the exercise of diplomatic protection. This paragraph is also justified on policy grounds. More refugees have serious complaints about their treatment at the hand of their State of nationality, from which they have fled to avoid prosecution. To allow diplomatic protection in such cases would be to open the floodgates for international litigation. Moreover, the fear of such demands might deter States from accepting refugees. Draft articles of the Convention deal only with the diplomatic protection of stateless persons and refugees. They are not concerned with the conferment of nationality upon such persons. The exercise of diplomatic protection should not be seen as giving rise to a legitimate expectation of the conferment of nationality. The Convention considers this kind of protection more as a progressive development of the right to diplomatic protection than as a codification of this protection.

\section{Conclusions}

In conclusion we may say that although citizenship is recognized as a sine qua non condition for the exercise of the diplomatic protection, the draft articles of the Convention on Human Rights present an innovative and progressive development of the right to diplomatic protection by including the protection to stateless persons and refugees. According to Crawford the condition of lawful and habitual residence sets a high limit to the exercise of diplomatic protection in respect of stateless persons. Therefore, the next challenge for $\mathrm{CHR}$ is to facilitate and enable the exercise of diplomatic protection to this category of individuals. Pursuant to international law, a state is responsible of the injuries caused to a foreign citizen resulting from its illicit actions or inactions. Diplomatic protection is the procedure initiated by the state of nationality of the injured person aimed at providing protection and compensation in respect of this person. Traditionally, diplomatic protection has been viewed as an exclusive right of the state, in the sense that a state is entitled to exercise diplomatic protection, for the reason that an injury caused to one of its citizens is considered as an injury caused to the state itself.

\footnotetext{
${ }_{17}$ John Dugard, First Report on diplomatic protection, s.177, p.58

18 This convention came into force on 09 Jun 2011

${ }^{19}$ Draft report with commentary, p. 49

20 Draft report with commentary, p. 49, Idem, p.50
} 


\section{References}

Arben Puto, International Public Law, Albin, 2008

Edwin Borchard, Diplomatic protection of citizens abroad, Bank Law Publisher

Co, NewDonald Richard Shea, The Calvo clause: a problem of inter-american and international law and diplomacy, University of Minnesota Press, 1995 York, 1915

Martin Dixon, International Law, Institute of International Studies

John Dugard, Fifth Report on diplomatic protection, UN doc/A/CN.4/538

Convention on the Reduction of Statelessness of year 1961 and Convention relating to the Status of Refugees of year 1951

D.J.Harris, Cases and materials on international law, Sweet\&Maxwell, 1998

Garcia Amador, State responsibility, Third report, yearbook 1958

Ian Brownlie, Principles of Public International Law 1998, Oxford, Fifth Edition 